\title{
Characterization of Desmodus rotundus (E. Geoffroy, 1810) (Chiroptera, Phyllostomidae) shelters in the Municipality of São Pedro - SP
}

\author{
Mialhe, PJ.* \\ Universidade Federal de São Carlos - UFSCar, Rodovia Washington Luis km 235, \\ CEP 13565-905, São Carlos, SP, Brazil \\ *e-mail:paulomialhe@gmail.com
}

Received June 5, 2012 - Accepted August 8, 2012 - Distributed August 31, 2013

(With 1 figure)

\begin{abstract}
Surveillance of hematophagous bats is an important public health measure for the prevention and control of rabies epidemics in domestic herbivorous animals. The aim of this study was to locate and georeference D.rotundus shelters in the Municipality of São Pedro - SP, Brazil, and verify their nature (artificial or natural), surrounding landscape and distance from main rivers. To do this, two samples were taken of populations in shelters, with an interval of six months between them, capturing all the bats existent in shelters with fewer than 20 individuals and approximately $20 \%$ of the bats present in shelters with over 20 individuals in order to quantify their gender and age distribution. The majority of $D$. rotundus $(67 \%)$ were verified to be artificial and the remainder (33\%) natural. Of the six artificial shelters found, five were located in abandoned houses and one in a rain water drainage channel. There were no signs of $D$. rotundus in other rural buildings and viaducts located in the proximities of pastures. In spite of the majority of $D$. rotundus shelters being artificial, the three most populated shelters were maternity colonies, two being located in grottos and only one in an artificial shelter (rain water drainage channel). The remaining shelters were occupied by only male individuals. With the exception of one shelter, all the other shelters were at a distance of less than $3 \mathrm{~km}$ from the main bodies of water in the study area, corroborating studies that have reported that the main rivers in the State of São Paulo are the main geographic features related to the presence of $D$. rotundus. It was also verified that $67 \%$ of the shelters were inhabited by only male individuals, which confirms other studies conducted in the State of São Paulo, in which over $60 \%$ of the groups of Desmodus contain only male individuals.
\end{abstract}

Keywords: hematophagous bats, population, shelters.

\section{Caracterização de Abrigos de Desmodus rotundus (E. Geoffroy, 1810, Chiroptera, Phyllostomidae) no Município de São Pedro - SP}

\section{Resumo}

A vigilância de morcegos hematófagos é uma importante medida de saúde pública para a prevenção e controle de epidemias de raiva nos herbívoros domésticos. O presente estudo teve como objetivos localizar e georreferenciar abrigos de D.rotundus no Município de São Pedro - SP e verificar sua natureza (artificial ou natural), paisagem de entorno e distância dos principais rios. Para isso, foram realizadas duas amostragens das populações nos abrigos, com intervalo de seis meses, capturando todos os morcegos existentes nos abrigos com menos de 20 indivíduos e aproximadamente $20 \%$ dos morcegos presentes nos abrigos com numero superior a 20 indivíduos a fim de quantificar sua distribuição sexual e etária. Verificou-se que a maioria dos abrigos de $D$. rotundus $(67 \%)$ era artificial e os restantes (33\%) naturais. Dos seis abrigos artificiais encontrados, cinco estavam localizados em casas abandonadas e um numa galeria de água pluvial, não havendo sinais de D. rotundus em outras construções rurais e viadutos localizados nas proximidades das pastagens. Apesar da maioria dos abrigos de D. rotundus serem artificiais, os três abrigos mais populosos eram maternidades, sendo que dois estavam localizados em grutas e apenas um em abrigo artificial (galeria de água pluvial). O restante dos abrigos era ocupado apenas por indivíduos machos. Com exceção de um, todos os outros abrigos estavam a uma distância inferior a $3 \mathrm{~km}$ dos principais corpos d'água da área de estudo, corroborando estudos que relatam que os principais rios do estado de São Paulo são as principais feições geográficas relacionadas à presença de $D$. rotundus. Também verificou-se que $67 \%$ dos abrigos eram habitados somente por indivíduos machos, o que confirma outros estudos realizados no Estado de São Paulo, em que mais de $60 \%$ dos agrupamentos de Desmodus contém somente indivíduos machos.

Palavras-chave: morcego hematófago, população, abrigos. 


\section{Introduction}

Desmodus rotundus, the common vampire bat, is widely distributed throughout the New World, and occurs from the North of Mexico through to the North of Argentina (MacNab ,1973; Greenhall et al., 1983; Koopman, 1988) being the most abundant species of hematophagous bat found in these regions. Economically, this species may cause great losses to the cattle raising industry in Latin America, because of its role in rabies transmission in herbivorous species (Greenhall et al., 1983; Acha \& Málaga-Alba,1988). Because of its feeding habit and its economic importance due to rabies transmission, it is one of the best known and studies species in the world (Bernard, 2005).

The species occurs both in forested areas and desert regions, sheltering in tree-hollows, caverns, drainage channels, abandoned mines and even in civil buildings (Bredt et al., 1998). Habitually, the colonies are small (Greenhall et al., 1983) and contain from 10 to 50 individuals; nevertheless, groups of 100 or more bats may occur, particularly where their populations are not regularly controlled (Uieda et al., 1996). Larger colonies (of around 300 individuals) have been observed by Sazima (1978) and Taddei et al. (1991) for the State of São Paulo and by Bredt et al. (1999), for the Federal District region.

There are reports of colonies in which males and females were found segregated within the same shelter, although it is more common to find aggregations of different sexes and ages. The groups appear to be stable for long periods, in which the members are capable of recognizing one another. In addition to diurnal shelters, there are temporary nocturnal shelters to which hematophagous bats retire after they have fed, and are the socalled digestion shelters. Vampire bats are known for sharing shelters with 45 other bat species (Greenhall et al., 1983).

Lord (1988) showed evidence that certain geographical characteristics determine elevated populations of $D$. rotundus. According to the author, areas close to the main rivers generally favor the existence of a larger number of shelters.

Similarly, Taddei et al. (1991), in a study at state level reported that the main rivers in the State of São Paulo were the main geographic features related to the presence of the bat, and doubling of a rabies epidemic in cattle in the 1980s, mentioning that the State of São Paulo municipalities covered by the main hydrographic basins were the most affected by the epidemic (Gomes et al., 2007).

The studies of Taddei et al. (1991) encouraged professionals from the coordinators of the cattle raisers defense - CDA ("Coordenadoria de Defesa Agropecuária"), the agency responsible for bovine rabies control in the State of São Paulo, to recommend that areas close to the main hydrographic basins in the State should be considered the most important for the development of shelters, and consequently, rabies epidemics in cattle (Peres et al., 2001). Thus, in the regions of disease surveillance, con- trol actions are linked to areas close to the main rivers. In view of the importance of actions of surveillance and control of these animals, and the non existence of studies on the population and spatial dynamics of D. rotundus in this municipality, the aim of the present study was to characterize the shelters of this bat species in the Municipality of São Pedro, SP, Brazil, with regard to its nature (artificial or natural), sample populations in the shelters in order to quantify the gender and age distribution, analyze the characteristics of the surrounding landscapes and verify the distance of shelters from the main rivers in the region.

\section{Materials and Methods}

This study was conducted between the months of December 2001 and October 2002 in the rural zone of the Municipality of São Pedro - SP, State of São Paulo, located at a latitude of $22^{\circ} 32^{\prime} 55^{\prime \prime}$ South and longitude $47^{\circ} 54^{\prime} 50^{\prime \prime}$ 'West, with an area of $619.75 \mathrm{~km}^{2}$ and altitudes ranging between 580 and 950 meters (IBGE, 2008). Its topography is composed of basalt cuestas and planes in the low lying areas, with a mean temperature ranging between $15{ }^{\circ} \mathrm{C}$ (minimum) and $28^{\circ} \mathrm{C}$ (maximum). The rural zone is composed of native forest on the slopes of valleys, and in the valleys and flatter regions, there is slaughter cattle and dairy cattle farming, table poultry farming, horse, pig, goat and sheep farming, in addition to plantations of sugarcane, eucalyptus, oranges and small subsistence farming. The location offers good shelter conditions (buildings unoccupied by humans, grottos, viaducts and tunnels) and favorable temperatures and resources (abundant food and water). The hydrography of the municipalities is composed of the Piracicaba river, that forms the Southern border with the Municipality of Piracicaba, in addition to the Pinheiros and Espraiado streams, and small Samambaia river.

Uninterrupted active searches were conducted for vampire bat shelters in the rural zone of the Municipality between December 2001 and October 2002. All the possible artificial shelters, such as bridges, viaducts, rural buildings whether they were abandoned or not, tunnels and rain water drainage channels were inspected. It was also possible to locate natural shelters thanks to interviews with rural property owners, who informed the location of grottos on their properties. After being located, the geographic coordinates were collected, using a GPS receiver model Garmim ${ }^{\circledR}$ - etrex, and the nature of shelters (natural or artificial) was determined. Populations in the shelters were estimated visually. Due to bats' habit of agglomerating, in shelters were there were large numbers of Desmodus rotundus, a visual calculation was made of the number of bats in a square meter, and then this number was multiplied by the total area occupied by the bats, thus obtaining the final result.

Information about shelters containing $D$. rotundus and the properties where these sites were found were recorded and worked on in the Geographic Information System MAPINFO 8.5, allowing preparation of a geo- 
referenced database that facilitated the work of data systematization, analysis and representation.

The geospatial database of bat shelters was superimposed on the spatial data of the hydrographic basins in the municipality, obtained from hydrographic charts of the Brazilian Geographic and Statistical Institute IBGE ("Instituto Brasileiro de Geografia e Estatística"), in the ratio of 1:50.000, of the municipalites of São Pedro (SF-23-Y-A-IV-1), Brotas (SF-22-Z-B-III-4), Santa Maria da Serra (SF-22-Z-B-VI-2) and Itirapina (SF-23-Y-A-I-3). This procedure allowed a thematic map to be prepared, with the goal of determining the distances between shelters and the hydric systems in the studied landscape.

After locating the shelters, the cattle-raisers defense office - EDA ("Escritório de Defesa Agropecuária") of Piracicaba, the agency linked to the cattle-raisers defense coordinators - CDA ("Coordenadoria de Defesa Agropecuária"), was informed about the fact, and sent a team to perform population control of D.rotundus, in the months of May and September 2002.

In order to perform control, the CDA team used special nets and traps to capture approximately $20 \%$ of the bats in the colonies, which then had their sex and reproductive state of females (empty, pregnant and nursing) identified. After this the bats were painted with anticoagulant paste based on Warfarin at a concentration of 1 to $2 \%$ in solid vaseline as the vehicle, and released to return to the shelter.

Due to the habit these bats have of mutually licking one another (cleaning and/or social interaction), and as the paste was applied to their dorsal region, it would be ingested by other bats (Piccinini et al., 1985; Kotait et al., 1998).

\section{Results}

\subsection{Spatial and population distribution of D. rotundus}

During the period from December 2001 to October 2002, 21 bat shelters were located in the Municipality of São Pedro, SP, of which 18 (86\%) were artificial and the remaining three (14\%) natural shelters (grottos). Among all of them, nine shelters (43\%) were inhabited by $D$. rotundus, with six being artificial and three natural. Up to the month of May 2002, six shelters containing $D$. rotundus were found (shelter numbers 1, 2, 5, 7, 8 and 9), all being artificial. In this month, cattle-raisers defense coordinators (CDA) - SP performed population control in these colonies, eliminating the $D$. rotundus that lived there.

From May to September 2002, D. rotundus were located in other three shelters (Shelter numbers 3, 4 and 6), all being natural (grottos). In the month of September, the colonies treated in May were re-evaluated, and $D$. rotundus was found only in Shelter No. 7 - Fazenda Aurora - with two individuals present. Table I shows the $D$. rotundus located during the period from December 2001 to September 2002, their geographic coordinates and the population existent in the month in which population control was performed by the CDA team.

\subsection{Characterization of the Desmodus rotundus shelters}

Shelter 1 was a rain water drainage channel, located under highway SP 304, which connected São Pedro to Santa Maria da Serra, km 213, at an altitude of 475 meters. It was 140 meters long, $1.60 \mathrm{~m}$ wide and $2.50 \mathrm{~m}$ high, and was internally lined with concrete. The surrounding landscape was formed of pasture, riparian shrub and small streams, one of which passed through the inside of the tunnel. The shelter was characterized as a maternity colony, with an estimated population of approximately 200 individuals. In May 2002, the CDA

Table 1 - Geographic Location and population of Desmodus rotundus existent in shelters in the Municipality of São Pedro, São Paulo during the year 2002.

\begin{tabular}{lcccccc}
\hline Shelter & No. & UTM Y & UTM X & Altitude (m) & \multicolumn{2}{c}{ Existent oopulation of D. rotundus } \\
\cline { 6 - 7 } & & & & & May 2002 & September 2002 \\
\hline Rain water drainage channel & 1 & 7500675 & 0804525 & 475 & 200 & 0 \\
Fz. Sta. Julia & 2 & 7505637 & 807930 & 520 & 2 & 0 \\
Fz. Sta. Maria & 3 & 7504165 & 196477 & 525 & 0 & 1 \\
Fz. Fazendão & 4 & 7504165 & 196477 & - & 0 & 62 \\
Sítio Sta. Olina & 5 & 7508350 & 198959 & 929 & 11 & 0 \\
Sítio Rancho Fundo & 6 & 7507369 & 198440 & 726 & 0 & 2 \\
Fz. Aurora & 7 & 7508612 & 0807873 & 919 & 2 & 0 \\
Usina São Pedro & 8 & 7498267 & 195475 & 558 & 1 & 0 \\
Fz. São Pedro & 9 & 7506686 & 193978 & 919 & - & 217 \\
Total & - & - & - & - & 65 \\
\hline
\end{tabular}


team performed a population control in this colony, capturing $36 \mathrm{D}$. rotundus, who were revealed to be 10 males (28\%), 11 empty females (31\%), 12 pregnant females $(33 \%)$ and three females with offspring $(8 \%)$, all the bat infants were males. In September of the same year, a new inspection was carried out at the site, and no D. rotundus was found.

Shelter 2 was located on a farm - Fazenda Santa Julia - in an abandoned brick house in a badly deteriorated state and without a ceiling, at an altitude of 520 meters. The surrounding landscape was composed of a pasture and sugarcane plantation. Due to the large quantity of feces at the site and the presence of only two male $D$. rotundus, the site was classified as a digestion shelter. The CDA ("Coordenadoria de Defesa Agropecuária") team applied anticoagulant paste on the two bats, and no bats were found during the inspection performed in September of that year.

Shelter 3 - Fazenda Santa Maria - was a small grotto located at an altitude of 525 meters, which had a single triangular-shaped entrance, measuring $1.60 \mathrm{~m}$ high by $1.80 \mathrm{~m}$ wide, reaching a depth of $4 \mathrm{~m}$. The grotto was formed of arenite rock, and in it there was a small source of water that formed a small pool approximately two and a half square meters in area and $50 \mathrm{~cm}$ deep. Afterwards it formed a stream that flowed through the property. Around this stream there was riparian shrub and pasture vegetation. In May 2002 no bats were found at the site, but on re-evaluation in September of the same year, only one male $D$. rotundus was found at the site.

Shelter 4 - Fazenda Fazendão - was a grotto composed of granite rock located in the Municipality of Brotas, close to the boundary with the Municipality of São Pedro. The surrounding landscape was composed of a sugarcane plantation, native shrubs and pasture. In May 2002 no D.rotundus had been found, however in September of the same year the site was inhabited by an estimated population of 62 D.rotundus, and it was classified as a maternity colony. Twelve individuals were sampled, with two being males (16.67\%), three empty females (25\%), four pregnant females $(33.33 \%)$ and three females with offspring (25\%). The CDA team ("Coordenadoria de Defesa Agropecuária") applied anticoagulant paste on these individuals and afterwards released them.

Shelter 5 - Sítio Santa Olina - was a badly deteriorated abandoned house without ceiling, located at an altitude of $929 \mathrm{~m}$. The surrounding landscape was composed of a pasture and a few sparsely scattered trees. In May 2002 eleven male D. rotundus were found, on which the CDA team applied anticoagulant paste and released them. In September of the same year no D. rotundus were found at this site. After the revision in September, the house was destroyed and close to the site, a picket fence was constructed for cattle management.

Shelter 6 - Sitio Rancho Fundo - was a grotto, located at an altitude of 726 meters, made up of various overlapping lumps of granite that formed a shelter with only one entry, approximately $2.5 \mathrm{~m}$ high by $2 \mathrm{~m}$ wide and approximately $18 \mathrm{~m}$ long, in a line sloping to the right. The surrounding landscape was composed of closed riparian shrub with a few trees, but by some streams that ran down the slope. During the first inspection in May 2002, no D.rotundus were found in the grotto, although there were other species of phyllostomid bats inhabiting the place. One of the species identified was the carnivorous bat Chrotopterus auritus (Peters, 1865, Chiroptera, Phyllostomidae) that has a large body size and large oval ears. There were approximately ten individuals. This species basically feeds on small vertebrates, including other bats. On a second inspection in September 2002, the cave was occupied by a population of the maternity type, estimated at 100 D.rotundus, of which the CDA team treated 30 bats with anticoagulant paste and released them in the grotto. Sexual and age distribution was not recorded in this colony.

Shelter 7 - Fazenda Aurora - was a badly deteriorated brick house without ceiling located at an altitude of $919 \mathrm{~m}$. The surrounding landscape was composed of a sugarcane plantation. In May 2002 two male D. rotundus were found, on which the CDA team applied anticoagulant paste. During the revision in September of the same year, another two D. rotundus were found, on which the CDA team repeated the anticoagulant paste treatment. It was classified as a digestion shelter due to the large quantity of $D$. rotundus guano existent at the site.

Shelter 8 - Usina São Pedro - was a badly deteriorated brick house without ceiling located at an altitude of $558 \mathrm{~m}$. The surrounding landscape was composed of a sugarcane plantation. In this house only one male $D$. rotundus was found and treated with anticoagulant paste, and in later revisions, no more $D$. rotundus were found.

Shelter 9 - Fazenda São Pedro - was a badly deteriorated brick house without ceiling located at an altitude of $919 \mathrm{~m}$. The surrounding landscape was composed of a pasture, sugarcane and eucalyptus plantations. In this house one male D. rotundus was found in May 2002, and in later revisions, no more $D$. rotundus were found. Table 1 presents the geographic location according to the Universal Transverse Mercator (UTM) coordinates and population of Desmodus rotundus existent in the shelters in the Municipality of São Pedro, SP, during the year 2002.

\subsection{Distance from the shelters to the closest rivers}

With the exception of Shelter 4 - Fazenda Fazendão all the other eight shelters were at a distance of less than 3 $\mathrm{km}$ from the main bodies of water in the study area. Figure 1 presents the location of the shelters in the Municipality of São Pedro, SP in a surrounding area of $3 \mathrm{~km}$ from the rivers, in which the shelters were located.

\section{Discussion}

The majority of $D$. rotundus shelters found were of the artificial type (67\%) and the remainder (33\%) were natural. This finding present a pattern similar to that found by Taddei et al. (1991) in São Paulo, relating that the artificial shelters are preferred by this species when they are located in cattle raising areas. 

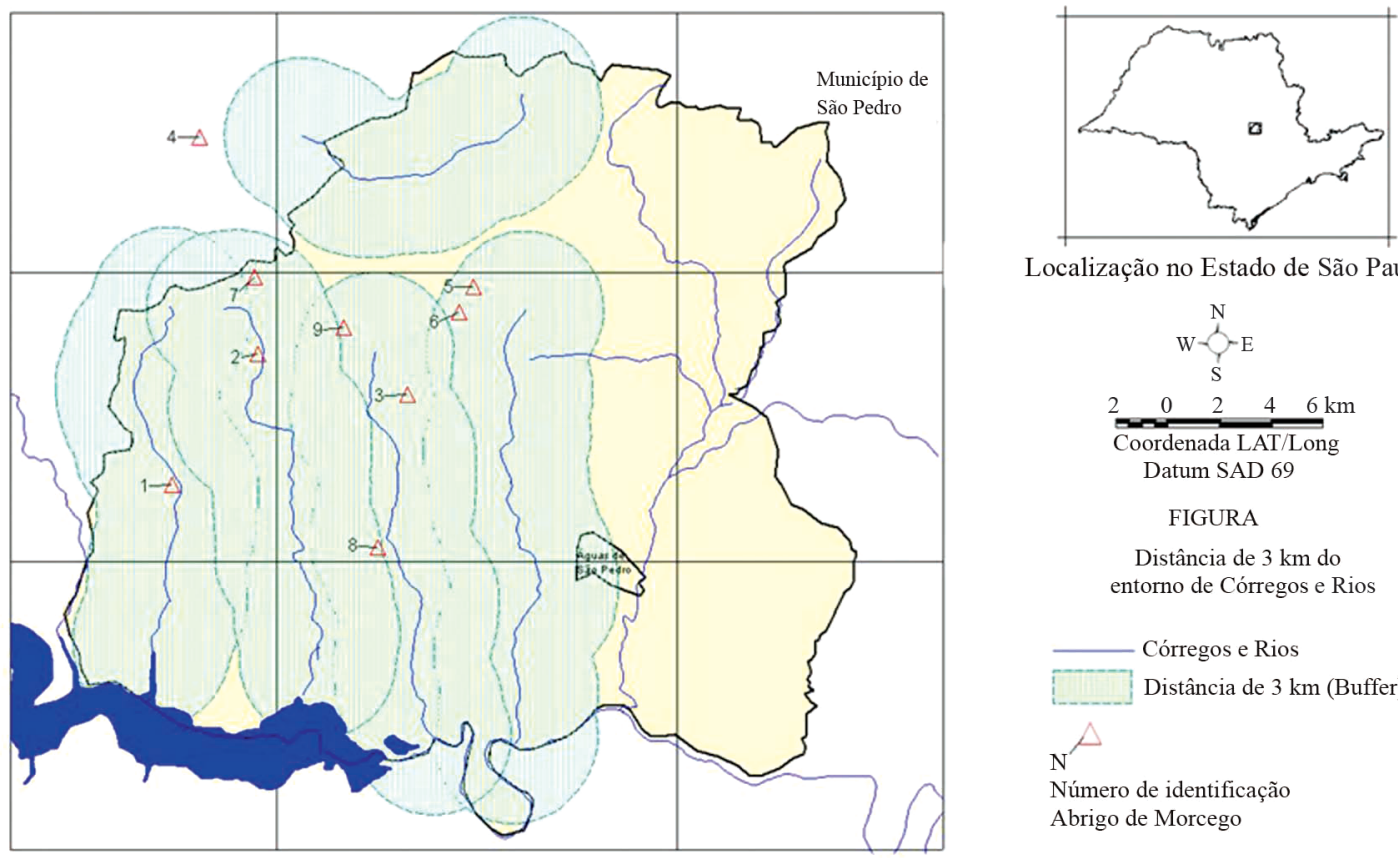

Localização no Estado de São Paulo

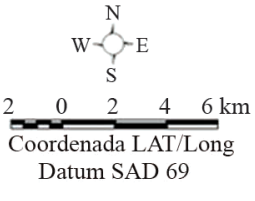

FIGURA

Distância de $3 \mathrm{~km}$ do entorno de Córregos e Rios

Córregos e Rios
Distância de 3 km (Buffer)

$\mathrm{N}^{\wedge}$

Número de identificação Abrigo de Morcego

Fonte: Planilha de Dados de Abrigos

Banco de Dados Digital LAPA/UFScar

Org: Laboratório de Análise e Planejamento Ambiental /UFScar

Figure 1 - Distance of $3 \mathrm{~km}$ from the main bodies of water in the study area, and location of hematophagous bat shelters.

In the Municipality of São Pedro, of the six artificial shelters found, five were located in abandoned houses. The absence of signs of $D$. rotundus in rural buildings and viaducts located in the proximities of pastures is an uncommon result, as under normal conditions these refuges are widely used by Desmodus rotundus (MalagaAlba, 1954). The transit of vehicles, animals and people through viaducts and in the proximities of rural constructions may have disturbed the presence of vampire bats in these sites, so that they would choose less busy places to establish their colonies.

In spite of the majority of $D$. rotundus shelters being artificial, the three most populated shelters were maternity colonies, two being located in grottos and only one in an artificial shelter (rain water drainage channel). With exception of the latter, all the other artificial shelters were abandoned houses, and few bats, all males, were found.

Only in Shelter 6 - Sítio Rancho Fundo - no sex and age sampling of bats was performed. Considering the total estimate of bats present in the eight remaining shelters, the presence of only $280 \mathrm{D}$. rotundus was counted, and 66 individuals (24\%) were sampled. The sex and age analysis of this sample revealed that $30 \mathrm{D}$. rotundus were males (45\%), 14 empty females (21\%), 16 pregnant females $(24 \%)$ and six females with offspring $(9 \%)$, all with male infants. This is equivalent to a ratio of $1.1 \mathrm{fe}-$ males: 1 male, data that approximate the studies of Wimsatt (1969) in Mexico and Crespo et al. (1961) and Nuñez \& Vianna (1998) in Argentina, who used the technique of marking and recapture, and collected a similar proportion of male and female individuals of D. rotundus in various studied shelters. Their data indicate a sexual ratio of approximately $1: 1$ in the colonies of this species. Only two colonies were within the size of 20 to 100 individuals, considered habitual (Wilkinson 1988, Greenhall et al., 1983, Greenhall 1993, Uieda et al., 1996) - Shelters 4 and 6, with 62 and 100 individuals respectively. In the State of São Paulo, Taddei et al. (1991) considered colonies with more than 52 individuals to be old, established colonies. In the present study, only one - Shelter 1 - had over 200 individuals. Uieda et al. (1996) considered that colonies larger than 100 individuals occur in regions where the work of population control is not performed regularly. Up to the year 2002, the CDA had performed no population control of D. rotundus in the Municipality of S. Pedro - SP. The remaining shelters (Shelter numbers $2,3,5,7,8$ and 9), equivalent to $67 \%$ of the shelters found, were inhabited by male $D$. rotundus, which confirms the studies of Uieda (1992) that in São Paulo, over $60 \%$ of the groups of Desmodus contain only males.

Wilkinson (1990) in their studies with D. rotundus in Costa Rica, says that the main body of a colony is composed mainly of females and their young, which are protected by a dominant male (alpha).Isolated individuals and small groups around the shelter were single males (or subordinates or satellites, that is, the lower-ranking alpha male). According UIEDA (2004), males singly or in small groups can be single males, waiting for an opportunity to mate with females of the main group. Therefore, the occurrence of $67 \%$ of Desmodus rotundus shelters 
containing only males could be due to the expulsion of these individuals by dominant males in maternity colonies, forming groups of single males.

In this study it was also possible to verify that with the exception of Shelter 4 , all the other 8 shelters were a distance of less than $3 \mathrm{~km}$ from the main bodies of water in the study area, corroborating the data found in other studies (Taddei et al., 1991) that related that the main rivers in the State of São Paulo are the main geographical features related to the presence of $D$. rotundus.

The information presented in this paper could be incorporated into other research aimed at better understanding the biology and ecology of this species, as well as programs for the eradication of animal rabies, which is held the control population of bats.

\section{References}

ACHA, PN. and MÁLAGA-ALBA, M., 1988. Economic losses due to Desmodus rotundus. In GREENHALL, AM. and SCHMIDT, U. (Eds.). Natural history of vampire bats. Boca Raton: CRC Press. p. 208-213.

BERNARD, E., 2005 Morcegos hematófagos: sangue, raiva e preconceito. Ciência Hoje, v.36, n.214. p.44-49.

BREDT, A., ARAUJO, FA., CAETANO JR, J., RODRIGUES, MGR., YOSHIKAWA, M. and SILVA, MMS., 1998. Morcegos em áreas urbanas e rurais: Manual de manejo $e$ controle. Brasilia: Ministerio da Saude, Fundação Nacional de Saude.

BREDT, A., UIEDA, W. and MAGALHÃES, ED., 1999. Morcegos cavernícolas da região do Distrito Federal, centro-oeste do Brasil (Mammalia, Chiroptera). Revista Brasileira de Zoologia, vol. 16, no. 3, p. 731-770.

CRESPO, JA., VANELLA, JMB., BLOOD, D. and DE CARLO, JM., 1961. Observaciones ecológicas del vampiro Desmodus rotundus en el norte de Córdoba. Revista del Museo Argentino de Ciencias Naturales Bernardino Rivadavia, vol. 4, no. 6, p. 131-160.

DOS REIS, NR., PERACCHI, AL., PEDRO, WA. and DE LIMA, IP., 2007. Morcegos do Brasil. Londrina: Nelio R. dos Reis. 253 p.

GREENHALL, AM., 1993. Ecology and bionomics of vampire bats in Latin America. In GREENHALL, AM., ARTOIS, M. and FEKADU, M. (Eds.). Bats and rabies. Lyon: Marcel Mérieux. p. 3-57.

GREENHALL, AM., JOERMANN, G., SCHMIDT, U. and SEIDEI, MR., 1983. Desmodus rotundus. Mammalian Species, vol. 202, p. 1-6.

IBGE - INSTITUTO BRASILEIRO DE GEOGRAFIA E ESTATÍSTICA, [s.n.]. Divisão Territorial do Brasil. Available

from
ftp://geoftp.ibge.gov.br/Organizacao/Divisao Territorial/2008/DTB_2008.zip. Access in: 01 jul. 2008.

KOTAIT, I., GONÇALVES, CA., PERES, NF., SOUZA, MCAM. and TARGUETA, MC., 1988. Controle da raiva dos herbivoros. São Paulo: Instituto Pasteur. Manual Técnico do Instituto Pasteur, no. 1.

MACNAB, BK., 1973. Energetics and the distribution of vampire bats. Journal of Mammalogy, vol. 31, p.227-268.

MACIEL, RRH., 2000. Ocorrência, Ciclicidade e Evolução de Focos de Raiva dos Herbivoros na Região da Grande Florianópolis e os Morcegos Hematófagos Desmodus rotundus (Chiroptera, Phyllostomidae). Florianopólis: UESC. Monografia apresentada para obtenção do grau de especialista.

MALAGA-ALBA, A., 1954. El vampiro portador de la rabia. Boletín de la Oficina Sanitaria Panamericana, vol. 37, p. 53-65.

NUÑEZ ,HA. and VIANNA, M.L., 1997. Estacionalidad reproductiva en el vampiro común Desmodus rotundus en el Valle de Lerma (Salta, Argentina). Revista de Biologia Tropical, vol. 45, no. 3, p. 1231-1235.

PICCININI, RS., FREITAS, CEA. and SOUZA, JCP., 1985. Vampiricidas de uso tópico em animais domésticos e em morcegos hematófagos. Pesquisa Veterinária Brasileira, vol. 5, p. 97-101.

SAZIMA, I., 1978. Aspectos do comportamento alimentar do morcego hematófago Desmodus rotundus. Boletim de Zoologia da Universidade de São Paulo, vol.3, p. 97-119.

TADDEI,VA., GONÇALVES, CA., PEDRO, WA., TADEI, WJ., KOTAIT, I., and ARIETA, C., 1991. Distribuição do morcego vampiro Desmodus rotundus no Estado de São Paulo e a raiva dos animais domésticos. Campinas: Impresso Especial da CATI.107p.

UIEDA, W., HAYASHI, MM., GOMES, LH. and SILVA, MMS., 1996. Espécies de quirópteros diagnosticadas com raiva no Brasil. Boletim do Instituto Pasteur, vol. 2, no. 1. p. 17-36.

UIEDA, W., 1992. Biologia e dinâmica populacional de morcegos hematófagos. In Segundo curso de atualização em raiva dos herbívoros, 1996. Curitiba. p. 63-87.

WILKINSON, G. S. 1988. Social organization and behavior. In Greenhall, AM., and SCHMIDT, U. (Eds). Natural History of Vampire Bats. Boca Raton: CRC Press. p. 85-95.

WINSATT, WA., 1969. Transient behavior, nocturnal activity patterns, and feeding efficiency of vampire bats (Desmodus rotundus) under natural conditions. Journal of Mammalogy, vol. 50, p. 233-44.

TADDEI, AV., GONÇALVES, CA., PEDRO, WA., TADEI, WJ., KOTAIT, I. and ARIETA, C., 1991. Distribuição do morcego vampiro Desmodus rotundus no Estado de São Paulo e a raiva dos animais domésticos. Campinas: Impresso Especial da CATI. 107 p. 